\title{
WHITE-WINGED SCOTER NEST IN RIPARIAN HABITAT NEAR THE BATTLE RIVER, SASKATCHEWAN
}

Spencer G. Sealy

Department of Biological Sciences

University of Manitoba

Winnipeg, MB R3T 2N2

Spencer.Sealy@umanitoba.ca

Most nests of the White-winged Scoter (Melanitta fusca) observed in Saskatchewan have been described as well hidden in shrubbery on large islands in large bodies of fresh water $^{1-2}$, particularly at Redberry Lake, Saskatchewan..$^{2-4}$ Fewer nests have been reported in riparian habitats, therefore, I document one placed amid Pussy Willow (Salix discolor), interspersed with Manitoba Maple (Acer negundo), about $30 \mathrm{~m}$ from the north shore of the Battle River $\left(52^{\circ} 43^{\prime} \mathrm{N}, 108^{\circ} 17^{\prime} \mathrm{W}\right), 1.5 \mathrm{~km}$ south of Battleford, Saskatchewan.

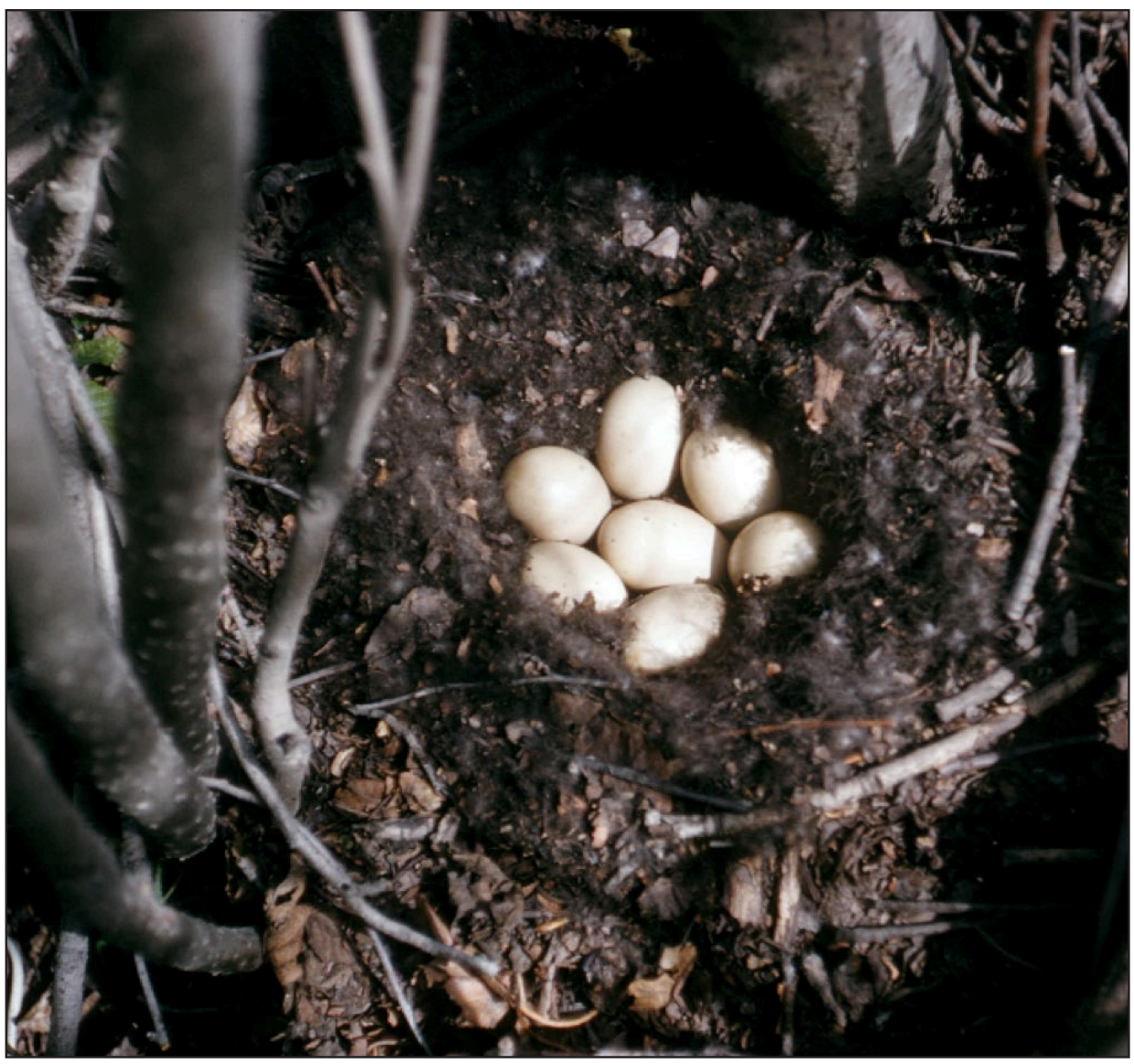

FIGURE 1. White-winged Scoter nest in riparian habitat along the Battle River, Saskatchewan, 27 June 1962. Photo credit: S.G. Sealy. observations made while I lived in Battleford (July 1958 through September 1961 and early May to mid-September 1962), and during occasional visits through 2016. I did, however, obtain three other records of White-winged Scoter: (1) one shot by Laurie B. Sealy on 17 October 1959 during the waterfowl hunting season at "Johnson's" Lake, 8 km south of Battleford; (2) an adult male observed circling a small, deep body of water, $7 \mathrm{~km}$ west of Battleford, on 5 August 1962; and (3) a freshly dead, adult female (not preserved) on a country road, $11 \mathrm{~km}$ southwest of Battleford, on 3 August 2005. About three decades earlier, 15 species of waterfowl were recorded in the Battlefords area during a six-week field camp held by the Provincial Museum, but the Whitewinged Scoter was not recorded.?

1. Godfrey WE (1950) Birds of the Cypress Hills and Flotten Lake regions, Saskatchewan. National Museum of Canada Bulletin, No. 120, Biological Series No. 40.

2. Houston CS (1955) White-winged Scoter banding. Blue Jay 13(4):28.

3. Brown PW, Brown MA (1981) Nesting biology of the White-winged Scoter. Journal of Wildlife Management 45:38-45.

4. Alisauskis RT (2019) White-winged Scoter. Pages 103-104 in Birds of Saskatchewan (Smith AR, Houston CS, Roy JF, editors). Nature Saskatchewan, Regina.

5. Brown PW, and Frederickson LH (1989) White-winged Scoter, Melanitta fusca, population and nesting on Redberry Lake, Saskatchewan. Canadian Field-Naturalist 103:240-247.

6. Farley FL (1932) Birds of the Battle River region of central Alberta. Institute of Applied Art, Edmonton, $A B$.

7. Belcher M (1972) An early Provincial Museum field camp in the Battleford area. Blue Jay 30:8-17. 